\title{
Biotechnology and Non-Bayesian Calculations for the Talus Bone Volume
}

\author{
Ahmed Al-Imam ${ }^{1-4 *}$ and Ma'an Al-Khalisy ${ }^{1}$ \\ ${ }^{1}$ Department of Anatomy and Cellular Biology, College of Medicine, University of Baghdad, Iraq. \\ ${ }^{2}$ CERVO Brain Research Centre, Faculty of Medicine, University of Laval, Canada. \\ ${ }^{3}$ IBM-Certified Specialist: SPSS Statistics. \\ ${ }^{4}$ Microsoft-Certified Data Analyst. \\ *Corresponding author: Ahmed Al-Imam, Department of Anatomy and Cellular Biology, College of Medicine, Iraq; CERVO Brain \\ Research Centre, Faculty of Medicine, Canada
}

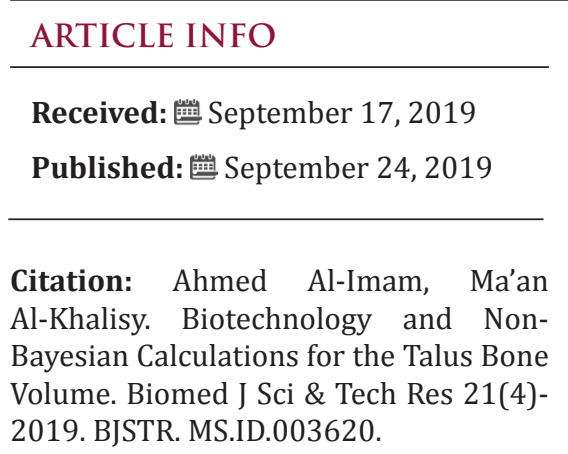

ABSTRACT

Keywords: Anatomy; Biotechnology; Non-Bayesian Statistics; Replica Techniques; Talus; Morphometry; Volumetry

\section{Opinion}

\section{Anatomical Science Research and Morphometric Studies}

Morphometric studies are versatile within the disciplines of human anatomy, comparative anatomical sciences, and physical anthropology [1,2]. The estimation of the volume of skeletal tissues, also known as Volumetry, represents an integral component of morphometry [3,4]. Anatomists and physical anthropologists developed a handful of methods to estimate the accurate size of bones as well as some soft tissues $[1,5]$. These techniques exploit cast materials, the Archimedes' principles of buoyancy and fluid displacement, replica manufacturing techniques, and radiologybased methods in addition to three-dimensional digital image analysis [5]. The morphometric studies of bones usually focus on quantifying and describing the morphology of irregular geometric shapes, the relevant dimensional parameters, the surface area of articular and the non-articular regions, and volumetric measurements of a whole bone or segments of bone, including tuberosities, tubercles, processes, cavities, sinuses, and others $[1,3,4,6]$. Volumetry can also apply to cartilaginous tissues and other chemically treated soft tissues of interest. Several morphometric studies neglect the analysis and quantification of volumes and surface areas. As a consequence, those studies are incomplete and of low level-of-evidence as per the proper critical appraisal tools of evidence-based medicine [7].

\section{The Talus Bone, AKA the Astragalus}

The talus, also known as the astragalus or the anklebone, is a bone of the tarsus. The tarsus forms the lower part of the ankle joint [8]. The anklebone articulates with the medial and the lateral malleoli of the tibia and the fibula [8]. Within the talo-calcaneonavicular joint, the astragalus maintains an enduring articulation with neighboring calcaneus and navicular bones [8,9]. For a stable upright posture and energy-economic bipedal locomotion, those sturdy articulations transmit the entire body weight to the foot $[8,9]$. The anklebone is also one of the bones in the human body to possess the highest surface area covered by articular cartilage. Perhaps, this may associate with its unique retrograde arterial blood supply [10]. In modern humans, there are no muscle attachments to the talus [9]. Its anatomic position is governed by the adjacent bones and ligaments-mediated topographic skeletal arrangement $[9,11]$. 


\section{Exploring the Literature for the Highest Level-of- Evidence}

We conducted a review of the literature, during the second half of September 2019, via the Cochrane Library [the Cochrane Database of Systematic Reviews], PubMed [the United States National Library of Medicine], and Embase [Elsevier Database | Scopus]. We pragmatically explored the peer-reviewed publications by deploying an elaborate mixture of MeSH-based keywords and generic terms, in combination with truncations as well as Boolean operators, to retrieve potential papers of the highest level-ofevidence in connection with our research topic. We applied keywords that relate to four major themes, including anatomical sciences, the talus bone, morphometric studies, and non-Bayesian between-subjects' statistics. Our review strategy yielded a total

Table 1A: Keyword-Based Exploration of the Principal Databases of Literature for Medical Research count of 494965 publications allocated into the Cochrane Library of Systematic Reviews [9310, 1.88\%], United States National Library of Medicine [306842, 61.99\%], and Embase [178813, 36.13\%] (Table 1A). Based on the combinatorial of the thematic keywords search of the literature and following a full-text retrieval of papers of interest, we were able to discover four potentially-relevant articles authored by Lin (2012), Shingler (2011), de Moraes Silva (2019), and Whitton (2015) (Table 1B). These studies originated from Australia, United Kingdom, Brazil, and the United Kingdom. All publications were systematic reviews, and all of these are indexed in the Cochrane Library as well as the PubMed database. However, only one study by Lin and coworkers (2012) was genuinely relevant to our study [11]. Accordingly, we conclude that there is a notable deficit for reliable and externally valid research of the highest levelof-evidence.

\begin{tabular}{|c|c|c|c|c|c|}
\hline \multirow[b]{2}{*}{ Theme of Keywords } & \multirow[b]{2}{*}{ Keywords } & \multicolumn{4}{|c|}{ Number of Hits per Database } \\
\hline & & $\begin{array}{c}\text { Cochrane Library } \\
\text { [Cochrane Database of } \\
\text { Systematic Reviews] }\end{array}$ & $\begin{array}{c}\text { PubMed [U.S. } \\
\text { National Library of } \\
\text { Medicine] }\end{array}$ & $\begin{array}{c}\text { Embase } \\
\text { [Elsevier } \\
\text { Database] }\end{array}$ & Total \\
\hline Anatomical Sciences & $\begin{array}{c}\text { anatomy OR anatom* OR human } \\
\text { anatomy OR human anatom* OR } \\
\text { comparative anatomy OR compar* } \\
\text { anat* OR physical anthropology OR } \\
\text { anthropology OR phys* anthr* }\end{array}$ & 1118 & 2736 & 28903 & 32757 \\
\hline Talus Bone & $\begin{array}{l}\text { Talus OR astragalus OR astragal OR } \\
\text { ankle OR bone ankle bone }\end{array}$ & 337 & 81646 & 10904 & 92887 \\
\hline Morphometric Studies & $\begin{array}{c}\text { morphometric studies OR } \\
\text { morphometry OR morphomet* OR } \\
\text { volumetric studies OR volumetry OR } \\
\text { volumet* }\end{array}$ & 109 & 93037 & 27538 & 120684 \\
\hline $\begin{array}{c}\text { Non-Bayesian } \\
\text { Between-Subjects } \\
\text { Statistics }\end{array}$ & $\begin{array}{l}\text { non-bayesian statistics OR non-bayes* } \\
\text { OR parametric statistics OR param* } \\
\text { stat* OR non-parametric statistics OR } \\
\text { non-param* stat* OR independent } \\
\text { t-test OR one-way ANOVA OR one- } \\
\text { factor ANOVA OR Pearson product } \\
\text { moment correlation OR point biserial } \\
\text { correlation OR Mann-Whitney U test } \\
\text { OR Kruskal-Wallis H test }\end{array}$ & 7742 & 129423 & 54028 & 191193 \\
\hline $\begin{array}{l}\text { Combination of } \\
\text { Themes }\end{array}$ & $\begin{array}{l}\text { (anatomy OR anatom* OR human } \\
\text { anatomy OR human anatom* OR } \\
\text { comparative anatomy OR compar* } \\
\text { anat* OR physical anthropology OR } \\
\text { anthropology OR phys* anthr*) AND } \\
\text { (Talus OR astragalus OR astragal } \\
\text { OR ankle OR bone ankle bone) } \\
\text { AND (morphometric studies OR } \\
\text { morphometry OR morphomet* OR } \\
\text { volumetric studies OR volumetry OR } \\
\text { volumet*) AND (non-bayesian statistics } \\
\text { OR non-bayes* OR parametric statistics } \\
\text { OR param* stat* OR non-parametric } \\
\text { statistics OR non-param* stat* OR } \\
\text { independent t-test OR one-way ANOVA } \\
\text { OR one-factor ANOVA OR Pearson } \\
\text { product moment correlation OR point } \\
\text { biserial correlation OR Mann-Whitney } \\
\text { U test OR Kruskal-Wallis H test) }\end{array}$ & 4 & 0 & $57440 \dagger$ & 57444 \\
\hline & Total & 9310 & 306842 & 178813 & 494965 \\
\hline
\end{tabular}

Date of the Review of Literature: $13^{\text {th }}-16^{\text {th }}$ of September 2019.

†Irrelevant Hits [Keywords Non-Sensitive Search] 
Table 1B: Systematic Review of the Literature: Highest Level-of-Evidence Studies.

\begin{tabular}{|c|c|c|c|c|c|c|}
\hline Title of Research & $\begin{array}{c}\text { Date of } \\
\text { Publication }\end{array}$ & $\begin{array}{c}\text { Number of } \\
\text { Authors }\end{array}$ & $\begin{array}{l}\text { Country of } \\
\text { Research } \\
\text { [Database] }\end{array}$ & $\begin{array}{l}\text { Database of } \\
\text { Literature }\end{array}$ & Topic of Research & Study Design \\
\hline $\begin{array}{l}\text { Rehabilitation for ankle fractures } \\
\text { in adults [http] }\end{array}$ & 2012 & 6 & Australia & $\begin{array}{c}\text { The Cochrane } \\
\text { Library }\end{array}$ & Ankle Fractures & Systematic Review \\
\hline $\begin{array}{l}\text { Compression stockings for the } \\
\text { initial treatment of varicose } \\
\text { veins in patients without venous } \\
\text { ulceration [http] }\end{array}$ & 2013 & 4 & United Kingdom & $\begin{array}{l}\text { The Cochrane } \\
\text { Library }\end{array}$ & Varicose Veins $†$ & Systematic Review \\
\hline $\begin{array}{l}\text { Balneotherapy for chronic } \\
\text { venous insufficiency [http] }\end{array}$ & 2019 & 4 & Brazil & $\begin{array}{l}\text { The Cochrane } \\
\text { Library }\end{array}$ & $\begin{array}{l}\text { Chronic Venous } \\
\text { Insufficiency } \dagger\end{array}$ & Systematic Review \\
\hline Interventions for vitiligo [http] & 2015 & 8 & United Kingdom & $\begin{array}{c}\text { The Cochrane } \\
\text { Library }\end{array}$ & Vitiligo † & Systematic Review \\
\hline
\end{tabular}

† Irrelevant Hits [Keywords Non-Sensitive Search]

\section{An Amalgamation of Biotechnology Experiments and Multi-Modal Non-Bayesian Statistics}

To achieve high computational precision and statistical accuracy in terms of sensitivity-specificity and predictive values, we shall conduct three modalities of biotechnology experiments to calculate the volume of the dry talus bone specimens that belong to both lower limbs, right and left. These include deploying the use of alginate-based cast materials, silicone-based cast replica manufacturing of the talus bone, as well as the implementation of Archimedes fluid displacement method for Volumetry [5]. To conclude with a rigour statistical inference on the right versus left tali comparison, we shall implement a plethora of non-Bayesian models of statistics for between-subjects testing, including Fisher's one-factorial ANOVA, William's independent t-test, and Pearson's product-moment correlation [in case of non-violation of normality and other parametric tests assumptions] (Figure 1) [12]. In case of violation of normality and parametric tests assumptions, we aim to achieve statistical extrapolation by using Point-Biserial correlation, Mann-Whitney $\mathrm{U}$ test, and Kruskal-Wallis $\mathrm{H}$ test. To assess the normality distribution of data, we shall implement either the Shapiro-Wilk test or Kolmogorov-Smirnov test. The goal of the multitude of triple-mode biotechnology experiments and the pre-planned octa-model statistical testing, is to accomplish a replicable study that is internally and externally-valid as well as being statistically robust with the least possible statistical errors [type-1 $(\alpha)$ and type-2 ( $\beta$ ) errors] [13-15].

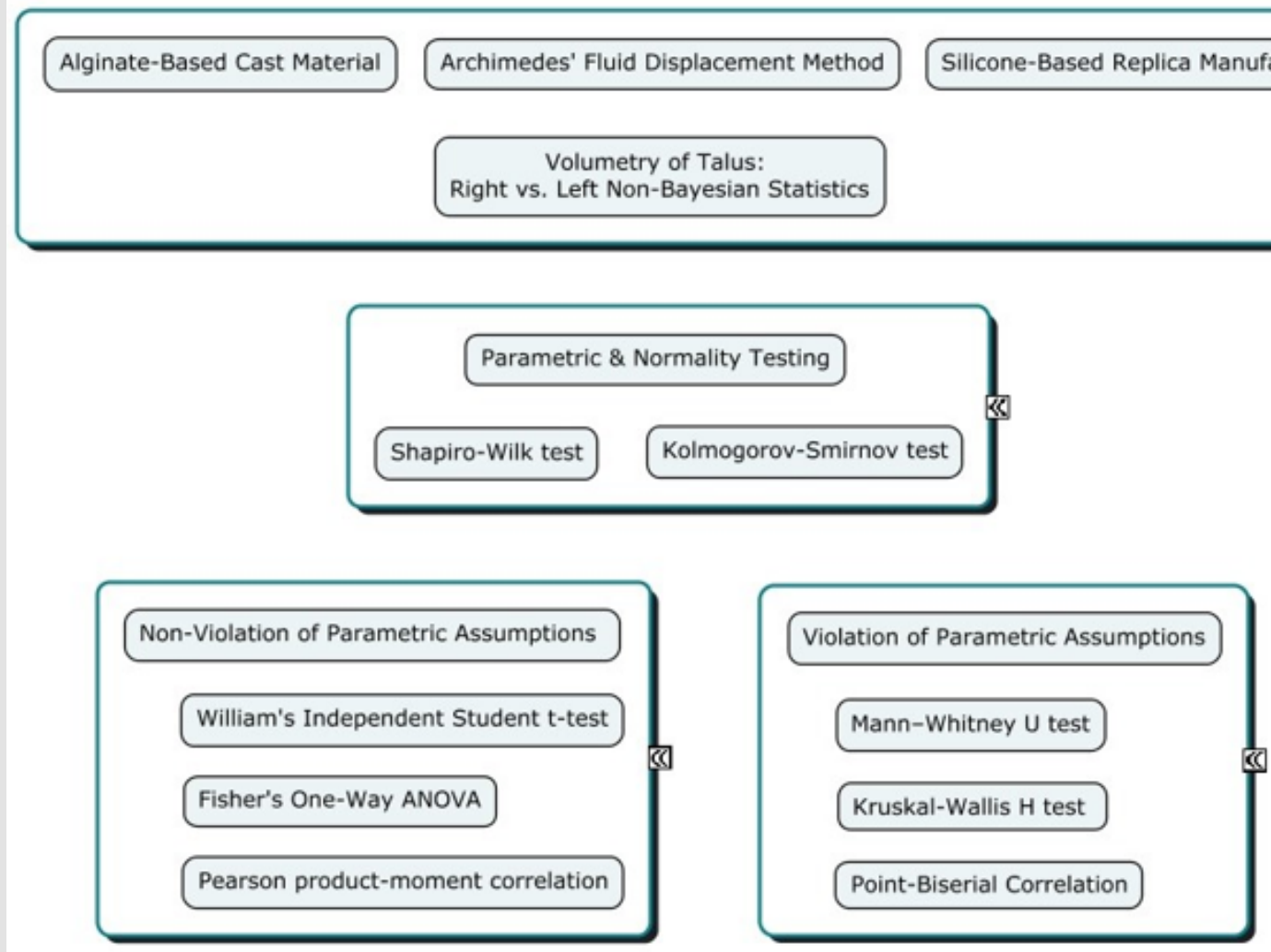

Figure 1: Volumetric Study Workflow: Quadri-Nodal and Tri-Hierarchical Concept Map. 


\section{High-Precision Multi-Modal Methodology for High- Impact Future Research}

High-impact anatomy researchers should aim for replicable and externally valid results of the talus bone morphometry $[13,16]$ We recommend a stepwise hierarchical approach to pragmatically

a. Conduct a systematic review of the databases of literature in connection with the primary objective, including relevant publications on the historical as well as the scientific aspects of the anklebone morphometry and its applied as well as clinical applications.

b. Optimize the systematic review of literature by deploying non-human mediated automated retrieval of publications of interest and the corresponding indexing data in real-time from the gold-standard established databases of the published literature in addition to the unpublished "grey" literature [17]. This step will require the implementation of high-level programming languages including MATLAB and Octave as well as spreadsheet templates and professional statistical packages for social sciences including SPSS, Stata, and Microsoft Excel with Data Analysis Tool Pak [18].

c. Create analytics based on the systematic review of literature in an attempt to discover a deficit that may portray some degree of statistical imprecision of the published literature.

d. Retrieve collateral data from online resources of interest, including Google Trends and Google Analytics open-source of big data.

e. Conduct multimodal biotechnology experimentation for morphometry of dry tali specimens.

f. Experiment with a hybrid of non-Bayesian statistical methods, including parametric and non-parametric models of hypothesis testing, in an aim to compute the talus volume and to infer an extrapolation for populations of interests.

g. Correlate the data with applied knowledge and clinically oriented applications in connection with musculoskeletal medicine, orthopedic surgery, rheumatology, and microvascular surgical specialties [19].

h. Disseminate the hierarchical knowledge by communicating collaborative and evidence-based knowledge with health organizations and global regulatory agencies of medical and research practice, thus aiming for a universal dissemination of unbiased information.

\section{References}

1. Bastir M, Torres Tamayo N, Palancar CA, Lois Zlolniski S, García Martínez D, et al. (2019) Geometric morphometric studies in the human spine. Spinal Evolution 361-386.
2. Al Imam A, Sahai A (2016) Morphometry of the superior articular surface of head of radius. Journal of the Anatomical Society of India 65(2): 104-113.

3. Oliveira JM, Alonso MB, De Sousa MJ, Fuziy A, Scocate AC, et al. (2017) Volumetric study of sphenoid sinuses: anatomical analysis in helical computed tomography. Surgical and Radiologic Anatomy 39(4): 367374.

4. Al Imam A, Al Zamili Z, Omar R (2017) Surface Area of Patellar Facets: Inferential Statistics in the Iraqi Population. Anatomy Research International 2685159

5. Al Imam A, Al Hadithi N (2017) A Biomedical Device Innovation: A Method for Accurate Calculation of Volume (Volumetry) of Irregular Bone Specimens. MedCrave Online Journal of Anatomy \& Physiology 4(4): 327-329.

6. Al Imam A, Al Imam M (2016) Human Patella Morphometry and Volumetry, An Osteology-based Study in the Japanese Ethnicity. European Journal of Pharmaceutical and Medical Research 3(10): 388396.

7. Sackett DL, Rosenberg WM, Gray JM, Haynes RB, Richardson WS (1996) Evidence based medicine. BMJ: British Medical Journal 312: 71.

8. Looze CA, Capo J, Ryan MK, Begly JP, Chapman C, et al. (2017) Evaluation and management of osteochondral lesions of the talus. Cartilage 8(1): 19-30.

9. Golanó P, Vega J, De Leeuw PA, Malagelada F, Manzanares MC, et al. (2010) Anatomy of the ankle ligaments: a pictorial essay. Knee Surgery, Sports Traumatology, Arthroscopy 18(5): 557-569.

10. Mulfinger GL, Trueta J, Pasadena, Barcelona (1970) The blood supply of the talus. The Journal of bone and joint surgery. British volume 52(1): 160-167.

11. Lin CW, Donkers NA, Refshauge KM, Beckenkamp PR, Khera K, et al. (2012) Rehabilitation for ankle fractures in adults. Cochrane database of systematic reviews.

12. Gelman A (2008) Objections to Bayesian statistics. Bayesian Analysis $3(3): 445-449$.

13. Calder BJ, Phillips LW, Tybout AM (1982) The concept of external validity. Journal of consumer research 9(3): 240-244.

14. Greenland S, Senn SJ, Rothman KJ, Carlin JB, Poole C, et al. (2016) Statistical tests, $\mathrm{P}$ values, confidence intervals, and power: a guide to misinterpretations. European journal of epidemiology 31(4): 337-350.

15. Strasak AM, Zaman Q, Pfeiffer KP, Göbel G, Ulmer H (2007) Statistical errors in medical research-a review of common pitfalls. Swiss medical weekly 137(3-4): 44-49.

16. Becker SP, Leopold DR, Burns GL, Jarrett MA, Langberg JM, et al. (2016) The internal, external, and diagnostic validity of sluggish cognitive tempo: A meta-analysis and critical review. Journal of the American Academy of Child \& Adolescent Psychiatry 55(3): 163-178.

17. Al Imam A (2017) Monitoring and Analysis of Novel Psychoactive Substances in Trends Databases, Surface Web and the Deep Web, with Special Interest and Geo-Mapping of the Middle East Pp. 1-316.

18. Al Imam A (2019) Inferential Analysis of Big Data in Real-Time: One Giant Leap for Spatiotemporal Digital Epidemiology in Dentistry. Odontostomatology Research Anatomy Learning \& Implantology 12(1): $1-14$.

19. Al Imam A, Sahai A, Al Nuaimi S, Ismail M (2018) The articular surfaces of the proximal segment of ulna: Morphometry and morphomechanics based on digital image analysis and concepts of fractal geometry. Journal of the Anatomical Society of India 67(1): 40-49. 


\section{ISSN: 2574-1241}

DOI: $10.26717 /$ BJSTR.2019.21.003620

Ahmed Al Imam. Biomed J Sci \& Tech Res

(c) (P) This work is licensed under Creative

Submission Link: https://biomedres.us/submit-manuscript.php

$\begin{array}{ll}\text { BIOMEDICAL } & \text { Assets of Publishing with us } \\ \text { RESEARCHES } & \text { Global archiving of articles } \\ \text { - Immediate, unrestricted online access }\end{array}$

